\title{
Arsenate DNA—Evidence for a Vital Force?
}

\author{
Alan W. Schwartz \\ Published online: 15 December 2010 \\ (C) The Author(s) 2010. This article is published with open access at Springerlink.com
}

The recent announcement of the discovery of a bacterium which is able to incorporate large amounts of arsenic in As-enriched and P-depleted environments has raised the fascinating hypothesis of a DNA analog in which arsenate diester linkages substitute for phosphodiester (www.sciencemag.org/content/early/2010/12/01/science.1197258). The data reported by Wolfe-Simon et al. show that the incorporated arsenate is associated with the extracted DNA of the cultures. While several interpretations of the data appear to be possible, the one suggested seems among the least likely. The authors acknowledge that arsenate esters are known to be orders of magnitude less stable than phosphate esters (Westheimer 1987), but speculate that specific vacuoles within the organism may stabilize the otherwise highly unstable As-DNA. While this is a striking argument, It does little to strengthen the highly circumstantial data presented in support of the dramatic role for As proposed. The burden of proof for such a conclusion lies firmly with the authors, who need to supply more convincing data than have thus far been published. Arguments concerning the possible influences of special environments are inadequate when appropriate biochemical techniques can be applied. To do so seems to invoke shades from the history of science, such as the concept of negative weight once ascribed to phlogiston, or even the "vital force" required to explain the phenomenon of optical activity.

Open Access This article is distributed under the terms of the Creative Commons Attribution Noncommercial License which permits any noncommercial use, distribution, and reproduction in any medium, provided the original author(s) and source are credited.

\section{References}

Westheimer FH (1987) Why nature chose phosphates. Science 235:1173-1178

A. W. Schwartz $(\bowtie)$

Radboud University Nijmegen, Nijmegen, The Netherlands

e-mail: alan@sci.ru.nl 